\title{
Institutional support for tribal farmer interest groups in Erode district of Tamil Nadu, India
}

\author{
Mathuabirami V* \\ Department of Agricultural Extension and Rural Sociology, Tamil Nadu Agricultural University, \\ Coimbatore - 641003 (Tamil Nadu), India \\ Kalaivani S \\ Department of Agricultural Extension and Rural Sociology, Tamil Nadu Agricultural University, \\ Coimbatore - 641003 (Tamil Nadu), India \\ ${ }^{*}$ Corresponding author. Email:mathuabirami09@gmail.com
}

\section{How to Cite}

Mathuabirami, V. and Kalaivani, S. (2021). Institutional support for tribal farmer interest groups in Erode district of Tamil Nadu, India. Journal of Applied and Natural Science, 13 (SI), 167 - 171. https://doi.org/10.31018/jans.v13iSI.2823

\begin{abstract}
Globally small and marginal tribal farmers situation is worse because of poor marketing system and lack of quality input and technical services. This worse situation can be empowered through group approach like Farmer Producer Organization (FPO), Farmers Interest Group (FIG) and Self Help Group (SHG). FIG is a self-managed, independent group of farmers with a shared goal and interest. This is usually formed by $15-20$ members. It is evidenced that the profitability in farming would be possible in groups rather than practising it individually. This is particularly the case where farmers organize themselves to respond to credit and input needs, marketing concerns, etc., as there are clear economic benefits of working in groups. The present study is aimed to investigate the level of institutional support for tribal Farmer Interest Groups (FIGs) in Erode district. A cent per cent of the respondents $(100.00 \%)$ admitted that they received support for getting information regarding input availability, subsidiary activities, various schemes of the state department of agriculture. The vast majority of the respondents received information on technical support on production aspects of crop production (98.00\%) and received credit support whenever needed (98.00\%). Institutions like NGOs, State Department of Agriculture played a major role in improving the standard of living of these tribal people. They received support from the institution from production to marketing and value addition. However, they did not get proper guidance for soil testing and quality testing of inputs. Because of remoteness, they received a medium level of institutional support.
\end{abstract}

Keywords: Farmers interest groups, Farmer producer organization, Institutional support, Tribes, Erode

\section{INTRODUCTION}

The government of India has promoted different forms of collectives, namely Farmer Producer Organizations (FPOs), Farmers Interest Groups (FIGs) to deal with the challenges faced by the small and marginal farmers (Department of Agriculture \& Cooperation, 2013). SHGs, FIGs, Co-operatives Producers Associations, marketing associations etc., had bestowed in maximizing the input-output ratio and finally increasing the profit of producers (Nain et al., 2015). Farmers confidence level was increased through the establishment of FIGs (Singh and Srinivasan, 1998).Around the globe, it is evidenced that the profitability in farming would be possible in groups rather than practising it individually. This is particularly the case where farmers organize them- selves as a response to credit and input needs, marketing concerns, etc., as there are clear economic benefits of working in groups. In areas where farmers are scattered geographically and communication is difficult, the importance of such organizations is greater. Such an organization creates an opportunity for farmers' participation and enables them to identify their own problems and find the best solution for their problems through group action. Thus it would also lead to build group cohesion and solidarity, which encourage mutual support. Many Governments and Non Governmental Organizations (NGO) had tried to organize farmers into groups and put together them into the advancement process by actively involving them in production, transfer of technology, planning, marketing, implementing and monitoring different developmental projects on 
agriculture rural development (Thamminaina, 2018).

Tamilnadu Tribes are maintaining their own way of life and they were settled mostly in heavily forested area. So they do not have access to modern technologies, which results in limited socio-economic significance. But they are blessed with valuable forest produces like timber, wood oil, honey, bee wax, resins, etc. Due to inaccessibility to the outer world, they were not getting a better price for their produce. There is a movement of tribal people from tribal to non-tribal areas, possibly searching for livelihood and educational opportunities. India's tribal population is over-dependent on agriculture and forest-related livelihood sources. While 43 per cent of non-tribals depend on agriculture, 66 per cent of the tribal population survives on these primary sector livelihood sources. But in recent decades, the number of tribal farmers is coming down, and more are becoming agricultural labourers. In the past decade, 3.5 million tribals have quit farming and other related activities. To overcome this situation FIG was established through which they can access credit, value addition of forest produce and market facilities. They were facing problems in getting quality inputs and good price for their produce, timely technical advice for production, protection, harvesting aspects of crop cultivation. Hence, they can be organized into a group with the support of the institution. With the support of state government, the Government of India was implementing different schemes for the welfare of tribal people.

Tribes were blessed with ample opportunities like forest resources for improving their livelihood. But geographical isolation restricts tribes to make use of their opportunities. They were facing problems in getting quality inputs and good price for their produce (Mathuabirami and Kalaivani, 2020a).FIG is an innovative approach to developing a value chain for the produce, establishing brand value, and linking the farmers with the market and consumers. It was promoted to collectivise production, especially at smallholder level, and empower them for better bargaining power. Tribal FIGs will play a unique role in improving the economic status of tribal people through which they can access credit, market facilities and value-added forest produce (Mathuabiramiet al., 2020b). FIG consists of 15 to 20 members. Agricultural production can be increased through prompt support like providing technical machineries, high-quality seeds and fertilizers and forward agriculture. In order to make all these facilities available to the tribal farmers, institutional supports are required. With the continuous support of the institutions, the agricultural sector can be sustained. And also, institutional support is much needed to boosting agricultural production for meeting the growing demand for agricultural produce (Engku et al., 2019). Institutions are facing struggles in visiting each and individual farmers and then for supporting farmers, establishing farmers interest groups. Thus tribal farmers need institutional support for organizing into groups, receiving forward and backward linkage. Patil et al. (2014) had studied the impact of collective action of farmers through FIG (Farmer Interest Group) and reported that the cost of cultivation was reduced through sharing inputs and also it will lead to gain additional profit. He also reported that that linking FIGs to institutional agencies would help for the empowerment of farmers. In this regard, the present study was conducted to study institutional support for the tribal FIGs.

\section{MATERIALS AND METHODS}

The research design adopted for this study is an expost-facto design. Erode district was purposively selected for conducting the study. Thus, Mysore Resettlement and Development Agency (MYRADA), Krishi Vigyan Kendra (KVK), Erode has been assigned as resource agency for promotion of one FPO in Erode district of Tamil Nadu supported under Tamil Nadu Small Farmers Agribusiness Consortium (TNSFAC) to increase the income level of the farmers by building, knowledge and facilitating supply inputs and linking to markets for produces. MYRADA KVK had planned to establish FPO through promoting Farmer Interest Groups (FIGs) concept among tribes. DimbamDhaniya Farmer Producer Company Limited (DDFPCL) comprised of 62 FIGs covering 27 villages. FIGs were federated into DDFPCL. Out of these 27 villages, nine villages were dominated by tribes: Chilumaiedoddi, Devarnatham, Pudhukadu, Guliyada, Sujjalakare, and KottamalamBejjalatti, Galidimbam and Ittarai. Four Tribal FIGs were randomly selected from 16 Tribal FIGs belonging to DDFPCL. By employing the whole sampling method, all the members of four selected FIGs were considered constituting a sample size of 100.

Based on Judge's opinion and review of the literature, a well-structured interview schedule was prepared, considering the objectives and the variables under study. The most relevant, unambiguous and practical questions were included in the schedule that was suitable to all categories of respondents, duly avoiding irrelevant items. Before giving a final shape to the interview schedule, the schedule was pre-tested in a non-sample area with $5 \%$ sample and necessary changes were made. Members of Tribal FIGs were personally contacted, surveyed with the help of an interview schedule and data were collected. The data collected were subjected to percentage analyses to get inferences. The details of selected Tribal FIGs are furnished in Table 1. 
Mathuabirami, V. and Kalaivani, S. / J. Appl. \& Nat. Sci. 13 (SI), 167 - 171 (2021)

\section{RESULTS AND DISCUSSION}

\section{Institutional support}

The distribution of respondents according to various Institutional support was investigated and the results are furnished in Table 2. It could be seen that cent percent of the respondents $(100.00 \%)$ received information regarding input availability, subsidiary activities, various schemes of state department of agriculture, vast majority of the respondents received information on technical support on production aspects of crop production $(98.00 \%)$ and received credit support whenever needed $(98.00 \%)$ followed by 97 per cent of the respondents who were assisted by the institution for organized into a group. It could also be noted from Table 2 that the majority of the respondents $(95.00 \%)$ received technical guidance regarding protection aspects of crop production, followed by 94 per cent of the respondents received support and technical guidance for marketing their products as well as informed about the markets which demand higher prices for their produce. The members of FIGs also received support such as technical guidance regarding qualitative aspects of crop production $(84.00 \%)$, received information regarding the time of sowing $(82.00 \%)$, technical guidance regarding farm equipment $(81.00 \%)$. They had buyback support from their institution $(79.00 \%)$ receive information on weather updates $(77.00 \%)$, received technical guidance on harvesting technique (77.00), received technical guidance on reducing the cost of cultivation $(70.00 \%)$, received technical guidance regarding post-harvest aspects of crop production (64.00\%). Only a few of the respondents received support for soil analysis $(23.00 \%)$ and quality testing of inputs $(30.00 \%)$. The present findings were in line with the study undertaken by Karthick (2014) among Farmer groups in Warangal District of Telangana, where the farmers groups received a medium level of institutional support. And also, the results were similar to work done by Ramanujam and Homiga (2014), where they elucidated that every three out of four members of SHG had got the support of NGOs and voluntary organizations being the members of SHGs.

\section{Overall levels of institutional support}

The levels of institutional support for the tribal Figs were analysed and the results are presented in Table 3. The results were analysed using mean and standard deviation as follows:

\begin{tabular}{lll}
\hline S. No & Criteria & Level \\
\hline 1. & <mean - Standard & Low \\
& Deviation & \\
& Mean - Standard & \\
deviation to Mean & Medium \\
& + Standard Devia- & \\
& tion & \\
& Mean + Standard & High \\
3. & Deviation & \\
\hline
\end{tabular}

From Table 3, it could be seen that the majority of the tribal FIG members $(83.00 \%)$ had received a medium level of Institutional support, followed by 10.00 per cent and 7.00 per cent at low and high levels of Institutional support, respectively. Because of remoteness, they were receiving a medium level of institutional support. They received institutional support from institutions such as MYRADA KVK, State Department of Agriculture, Forest Department. These institutions gave technical guidance from production to marketing of crops, value addition of Non-Wood Forest Produces, and members of FIGs were well informed about various schemes for tribal welfare. They also received credit support during the needy situation. Therefore, the present findings were contradictory with the results of Karthick (2014), who indicated that in case of Cotton farmer groups in Warangal District of Andhra Pradesh, the majority $(30.00 \%)$ of respondents received high support followed by medium $(27.50 \%)$, very high $(17.50 \%)$, very low $(15.00 \%)$ and low $(10.00 \%)$ level of institutional support from agricultural agencies.

\section{Conclusion}

Institutions like NGOs and the State Department of Agriculture play a major role in improving the standard of living of the tribal people. Institutional support is still very relevant and important in the development of tribal people. Institutions (NGOs, State Department) have been established to increase returns for tribal farmers

Table 1. Details of selected tribal FIGs in Erode district.

\begin{tabular}{llll}
\hline S.No. & Name of the village & Name of FIG & No. of members \\
\hline 1 & & KadehattiMuniyappan FIG & 15 \\
2 & Guliyada & Periyasamyaiyyan FIG & 16 \\
3 & Sujjalakare & Sri Karppusamy FIG & 25 \\
4 & Kottamalam & Sri Magaliamman FIG & 24 \\
5 & Ittari & Ilandhalir FIG & 20 \\
\hline Total & & 100 \\
\hline
\end{tabular}


Table 2. Distribution of respondents according to institutional support $(n=100)$.

\begin{tabular}{|c|c|c|c|}
\hline S. No. & Statements & No. & $\%$ \\
\hline 1. & I receive information regarding source of input availability. & 100 & 100.00 \\
\hline 2. & $\begin{array}{l}\text { I receive technical guidance regarding production aspects of crop } \\
\text { production. }\end{array}$ & 98 & 98.00 \\
\hline 3. & $\begin{array}{l}\text { I receive technical guidance regarding protection aspects of crop } \\
\text { production. }\end{array}$ & 95 & 95.00 \\
\hline 4. & I receive support for soil analysis. & 23 & 23.00 \\
\hline 5. & $\begin{array}{l}\text { I receive technical guidance regarding qualitative aspects of crop } \\
\text { production. }\end{array}$ & 84 & 84.00 \\
\hline 6. & $\begin{array}{l}\text { I receive technical guidance regarding post harvest aspects of crop } \\
\text { production. }\end{array}$ & 64 & 64.00 \\
\hline 7. & I receive technical guidance on reducing cost of cultivation. & 70 & 70.00 \\
\hline 8. & I receive technical guidance regarding farm equipments. & 81 & 81.00 \\
\hline 9. & I receive credit support when needed. & 98 & 98.00 \\
\hline 10. & $\begin{array}{l}\text { I receive information on various schemes of department of agricul- } \\
\text { ture and allied departments. }\end{array}$ & 100 & 100.00 \\
\hline 11. & I receive technical guidance regarding market prices. & 94 & 94.00 \\
\hline 12. & I have back support from my institution. & 79 & 79.00 \\
\hline 13. & $\begin{array}{l}\text { I am being informed of the markets which demand higher prices of } \\
\text { crop produce. }\end{array}$ & 94 & 94.00 \\
\hline 14. & I receive support for subsidiary activities. & 100 & 100.00 \\
\hline 15. & I receive technical guidance regarding harvesting technique. & 77 & 77.00 \\
\hline 16. & I am assisted by my organization to be organized into group. & 97 & 97.00 \\
\hline 17. & I receive information regarding time of sowing & 82 & 82.00 \\
\hline 18. & I am being informed of quality testing of inputs. & 30 & 30.00 \\
\hline 19. & I receive information on weather updates. & 77 & 77.00 \\
\hline 20. & $\begin{array}{l}\text { I am supported by my organization to maintain field operation book } \\
\text { and regarding group operations. }\end{array}$ & 92 & 92.00 \\
\hline
\end{tabular}

Table 3. Level of institutional support received by members of tribal farmer interest groups in Erode district $(n=100)$.

\begin{tabular}{|c|c|c|c|}
\hline S.No. & Category & Number & Per cent \\
\hline 1. & Low & 10 & 10.00 \\
\hline 2. & Medium & 83 & 83.00 \\
\hline 3. & High & 7 & 7.00 \\
\hline \multicolumn{2}{|c|}{ Total } & 100 & 100.00 \\
\hline
\end{tabular}


through increasing agricultural production. Institutions were promoting group approaches like FIGs, Farmer Producer Organization (FPO), Commodity Interest Groups (CIGs). Thus the findings of the study revealed that the tribal farmers received a medium level of institutional support from production to marketing of agricultural produce. Still, more efforts should be taken by institutions for providing buyback support of agricultural produce, value addition of agriculture, and NWFPs who make farmers go for soil testing by enabling them to understand the importance of soil analysis and insist them to go for quality testing of inputs.

\section{Conflict of interest}

The authors declare that they have no conflict of interest.

\section{REFERENCES}

1. Department of Agriculture \& Cooperation (2013). Policy and process guidelines for farmer producer organizations. Ministry of Agriculture, Government of India.

2. Engku Elini Engku Ariff, Hairazi Rahim, Rosnani Harun \& Asruldin Ahmad Sobri (2019). Fragrant rice overview: Benefits and implications of local production. Economic and Technology Management Review, 14, 01 - 11

3. Karthick, D. (2014). A study on the effectiveness of cotton farmer groups in Warangal district of Andhra Pradesh. M.Sc. (Ag.) Thesis, Acharya NG Ranga Agricultural University, Rajendranagar, Hyderabad
4. Mathuabirami, V.\& Kalaivani, S. (2020a). An analytical study on relationship of profile characteristics with effectiveness of tribal FIGs in Tamil Nadu. Madras Agricultural Journal, 107(4-6), 216-219.

5. Mathuabirami, V., Kalaivani, S., Premavathi, R. \& Radha, M. (2020b). Analysis on effectiveness of tribal farmer interest groups (FIGs) in Tamil Nadu. International Journal of Agricultural Science and Research, 10 (4), 169-174.

6. Nain, M.S., Rashmi Singh., Shiv Kumar \& Chahal,V.P. (2015) Farmers producer organization in reducing transactional costs: A study of Tamil Nadu mango growers federation (TAMAFED). Indian Journal of Agricultural Sciences, 85 (10), 1303-7

7. Patil, Suresh., Hiremath, G.M., \& Lokesh, G.B. (2014). Economic sustainability through farmers interest groups and their linkage with institutional agencies-An evidence from Karnataka. Agricultural Economics Research Review, 27,141-146.

8. Ramanujam, V., \& Homiga, U. (2014). A study on the performance of self help groups in Mysore district. International Journal of Business and Administration Research Review, 3 (6), 190-196.

9. Singh, K. \& Srinivasan, R.(1998). Role of farmers' organization in the context of new economic policy with particular reference to agriculture marketing and agroprocessing.Indian J. Agril. Mktg., 161-164. Retrived from http://ap.fftc.agnet.org/ap_db.php?id=737\&print=1

10. Thamminaina, A. (2018).Catalysts but not magicians: Role of NGOs in the tribal development. SAGE Open, 8 (2), 2158244018785714. Doi: 10.1177/2158244018785 714 